short, anteriorly scutellate, laterally reticulate; hind toe wanting; anterior toes scutellate, of moderate length, connected by emarginate webs, the inner toe much shorter than the outer, which is nearly as long as the middle. Claws rather small, slightly arched, compressed, rather acute.

Plumage dense, blended, rather glossy on the upper parts. Wings of moderate length, narrow, pointed; primaries tapering, the first longest, the rest rapidly graduated, secondaries rounded. Tail very short, even, of sixteen elastic feathers.

Bill orange-yellow; feet greyish-yellow. The general colour of the upper parts is black, as are the cheeks, the upper part of the fore neck and its sides; the lower parts white. Two decurved white bands on the sides of the head, one commencing over the eye, the other at the angle of the mouth, both being formed by elongated, linear, acuminate feathers. The shafts of the wing-feathers are reddish-brown above, white beneath.

Length to end of tail $15 \frac{1}{2}$ inches, to end of claws $16 \frac{3}{4}$; bill along the ridge $1 \frac{5 \frac{1}{2}}{12}$, not including the outline of the knob, which is $\frac{4 \frac{1}{12}}{12}$ high, along the edge of lower mandible $1 \frac{10}{12}$, breadth of upper mandible below the knob, $\frac{2 \frac{1}{5}}{8}$; wing from flexure $6 \frac{10}{12}$; tarsus $1 \frac{4 \frac{1}{2}}{12}$; inner toe $1 \frac{2}{12}$, its claw $\frac{5}{12}$; middle toe $1 \frac{1}{2}$, its claw $\frac{5 \frac{1}{2}}{12}$; outer toe $1 \frac{5}{12}$, its claw $\frac{5}{12}$.

\title{
THE LARGE-BILLED GUILLEMOT.
}

\author{
† Uria Brunnichit, Sabine.
}

\section{PLATE CCCCLXXII.-Adult MaLe.}

I have never observed this bird on any part of the coast of our Middle Districts, and, although I was told that it not unfrequently occurred about the Bay of Boston, I failed in my endeavours to procure it there. The specimen from which my figure was made was sent to me in ice, along with several other rare birds, from Eastport in Maine. I received it quite fresh and in excellent plumage, on the 18th of February, 1833. It had been shot along with several other individuals of the same species while searching for food in the waters of Pasmaquody Bay, which were then covered with broken ice. Its flight was described by Mr. Curtis, who sent it to me, as

VoL. VII. 
similar to that of the Foolish Guillemot, with which it associated. No other information was transmitted, excepting that it dived and swam like the other species. I afterwards sent the skin to my friend the Rev. John Bachman, in whose collection it remains.

No individuals of this species were observed by my party on our way to Labrador; and as the Foolish Guillemot was abundant on the coast of that country, I concluded that the Thick-billed Guillemots which visit our eastern seas in winter, set out for the far north at an earlier period than the others. I am indebted to Mr. Hewitson of Newcastle, author of the "British Oology," for a description of an egg of this bird, which is in the valuable collection of the Messrs. Hancocks, who procured it from Greenland. It measures $3 \frac{1}{8}$ inches in length, by $2 \frac{1}{8}$ at its broadest part, and is of a bluish-green colour, streaked and spotted with black or very dark umber.

Male, $18 \frac{1}{2}, 30$.

Occasionally procured in Maine. Not very rare off the coast of Nova Scotia. Breeds from Hudson's Bay to the Arctic Seas.

Uria Brunnichir, Bonap. Syn., p. 424.

Uria Brunnichil, Brunnich's Guillemot, Swains. and Rich. F. Bor. Amer., vol. ii. p. 477.

Large-billed Guillemot, Nutt. Man., vol. ii. p. 529.

Large-billed Gullemot, Uria Brunnichii, Aud. Orn. Biog., vol. iii. p. 336.

\section{Adult Male in winter.}

Bill shorter than the head, stout, tapering, compressed, acute. Upper mandible with the dorsal line slightly curved, the ridge narrow, broader at the base, the sides sloping, the edges sharp and inflected, the tip a little decurved, with a slight notch. Nasal groove broad, feathered; nostrils at its lower edge, sub-basal, lateral, longitudinal, linear, pervious. Lower mandible with the angle medial, narrow, the dorsal line sloping upwards and straight, the back very narrow, the sides nearly flat, the edges sharp and inflected.

Head large, oblong, depressed, narrowed before. Eyes of moderate size. Neck short and thick. Body stout, rather depressed. Wings small. Feet short, placed far behind; the greater part of the tibia concealed, its lower portion bare; tarsus short, stout, compressed, anteriorly sharp, and covered with a double row of scutella, the sides with angular scales; toes of moderate length, the first wanting, the third longest, the fourth longer than the second, all covered above with numerous scutella, webbed, the lateral ones with small margins; claws small, slightly arched, compressed, rather acute, that of the middle toe largest, with a dilated inner edge.

Plumage dense, very soft, blended; on the head very short. Wings 
rather short, narrow, acute; primary quills curved, tapering, the second longest, the first slightly shorter, the rest rapidly graduated; secondaries short, incurved, broad, rounded. Tail very short, rounded, of twelve narrow feathers.

Bill black. Iris dark brown. Feet dusky, tinged with red. The general colour of the plumage is greyish-black on the upper parts, those of the head tinged with brown. The sides of the head and neck, its fore part, the breast, abdomen, edges of the wings and the tips of the secondaries, white; the sides shaded with greyish-black; a line of the same behind the eye.

Length to end of tail $18 \frac{1}{2}$ inches, to end of claws $21 \frac{1}{2}$; extent of wings 30 ; wing from flexure 8 ; tail $2 \frac{1}{2}$; bill along the ridge $1 \frac{2}{12}$, along the edge of lower mandible 2 ; tarsus $1 \frac{4}{12}$; middle toe $1 \frac{8}{12}$, its claw $\frac{5}{12}$. Weight $2 \frac{1}{4}$ lbs.

\title{
THE FOOLISH GUILLEMOT.-MURRE.
}

\author{
Uria Troile, Linn.
}

\section{- Plate CCCClXXiII.-Male and Female.}

This bird is seldom found farther south than the entrance of the Bay of New York, where, however, it appears only during severe winters, for being one of the most hardy inhabitants of the northern regions, its constitution is such as to enable it to bear without injury the rigours of their wintry climates. About the bays near Boston the Guillemots are seen every year in greater or less numbers, and from thence to the eastward they become gradually more abundant. A very old gunner whom I employed while at Boston, during the winter of 1832-3, assured me, that when he was a young man, this species bred on many of the rocky islands about the mouth of the bay there; but that for about twenty years back none remained after the first days of April, when they departed for the north in company with the Thickbilled Guillemot, the Common Auk, the Puffin, and the Eider and King Ducks, all of which visit these bays in hard weather. In the Bay of Fundy, the Foolish Guillemot is very numerous, and is known by the name of Murre, which it retains among all the eggers and fishermen of Newfoundland and Labrador, where it breeds in myriads. To those countries, then, I 
$\frac{\mathfrak{2}}{2}$
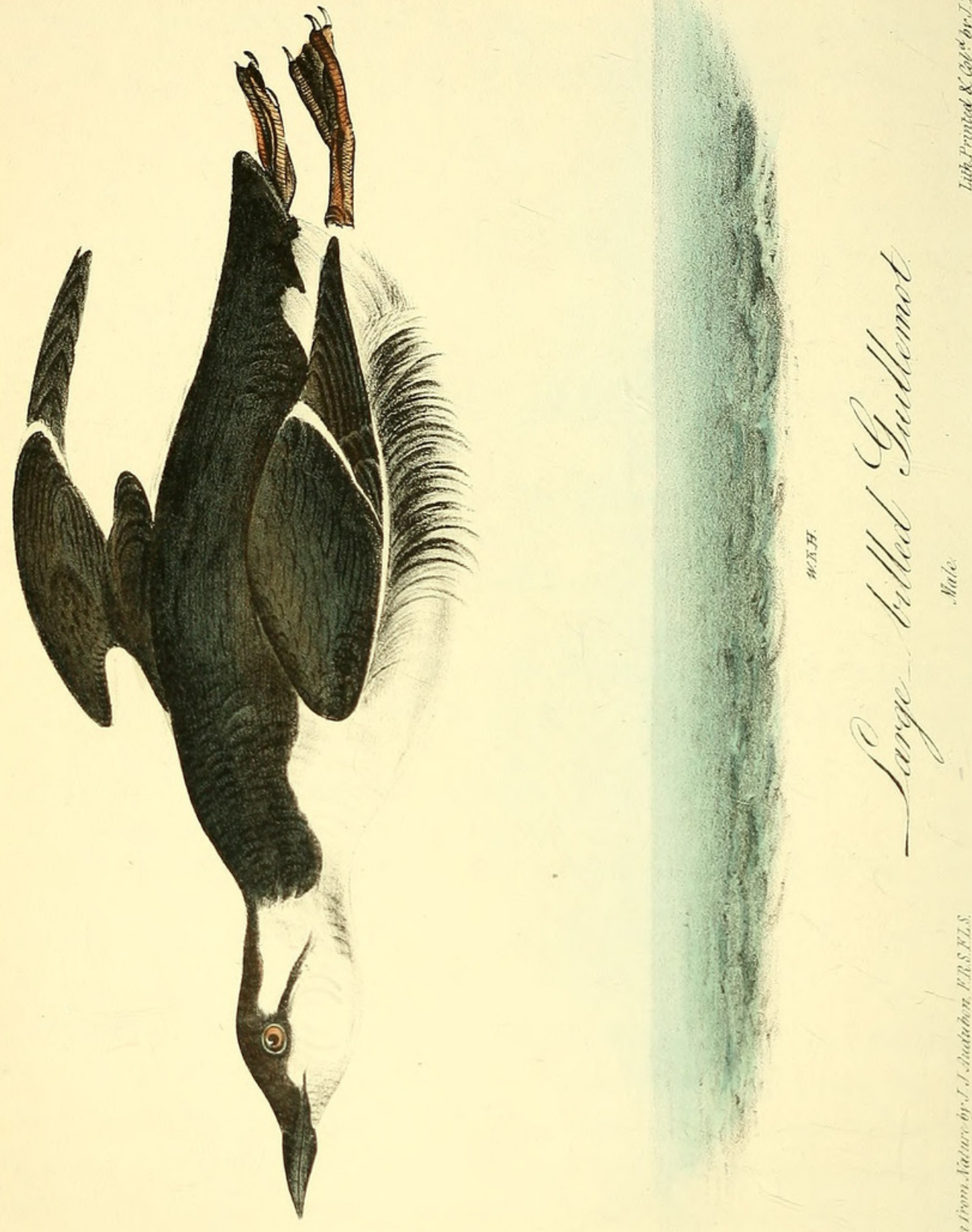

10
8 


\section{$2 \mathrm{BHL}$ Biodiversity Heritage Library}

Audubon, John James. 1844. "The Large-Billed Guillemot, Uria brunnichii, Sabine. [PI. 472]." The birds of America : from drawings made in the United States and their territories 7, 265-267. https://doi.org/10.5962/p.319589.

View This Item Online: https://www.biodiversitylibrary.org/item/124981

DOI: https://doi.org/10.5962/p.319589

Permalink: https://www.biodiversitylibrary.org/partpdf/319589

\section{Holding Institution}

Smithsonian Libraries

\section{Sponsored by}

Biodiversity Heritage Library

\section{Copyright \& Reuse}

Copyright Status: NOT_IN_COPYRIGHT

This document was created from content at the Biodiversity Heritage Library, the world's largest open access digital library for biodiversity literature and archives. Visit BHL at https://www.biodiversitylibrary.org. 